\title{
Pengaruh Foot Massage terhadap Kualitas Tidur Pasien di Ruang ICU
}

\author{
Nurlaily Afianti', Ai Mardhiyah ${ }^{2}$ \\ ${ }^{1}$ RS Hasan Sadikin, ${ }^{2}$ Fakultas Keperawatan Universitas Padjadjaran \\ Email:nurlaily.afianti@gmail.com
}

\begin{abstract}
Abstrak
Gangguan tidur pasien kritis di ruang Intensive Care Unit dapat mengakibatkan terganggunya fungsi kekebalan tubuh, menurunkan kemampuan otot inspirasi pernafasan, terganggunya sistem metabolisme, terganggunya regulasi sistem saraf pusat dan kondisi psikologis pasien yang berdampak terhadap waktu perawatan berkepanjangan. Foot Massage merupakan salah satu terapi komplementer yang aman dan mudah diberikan dan mempunyai efek meningkatkan sirkulasi, mengeluarkan sisa metabolisme, meningkatkan rentang gerak sendi, mengurangi rasa sakit, merelaksasikan otot dan memberikan rasa nyaman pada pasien. Tujuan penelitian ini teridentifikasinya perbedaan pengaruh skor kualitas tidur pada kelompok kontrol dan perlakuan. Penelitian quasi eksperimental ini menggunakan kelompok kontrol dan kelompok perlakuan dengan masing-masing kelompok dilakukan penilaian pretest dan postest. Jumlah sampel sebanyak 24 pasien. Instrumen kualitas tidur menggunakan Richard Campbell Sleep Quationare (RCSQ). Data dianalisis dengan uji t berpasangan dan uji t tidak berpasangan. Hasil penelitian menunjukan pada kelompok kontrol tidak terdapat perbedaan yang bermakna rerata skor kualitas tidur $(\mathrm{p}=0,150)$, sedangkan pada kelompok perlakuan, terdapat perbedaan yang bermakna rerata skor kualitas tidur $(p=0,002)$. Adapun selisih skor kualitas tidur pada kelompok kontrol dan kelompok perlakuan terdapat perbedaan secara bermakna $(p=0,026)$. Simpulan penelitian ini skor kualitas tidur pada kelompok intervensi lebih tinggi daripada kelompok kontrol, sehingga disarankan foot massage dijadikan evidence based di rumah sakit sebagai salah satu terapi komplementer yang dapat dijadikan intervensi mandiri keperawatan untuk membantu mengatasi gangguan tidur pasien kritis.
\end{abstract}

Kata kunci: Foot massage, ICU, kualitas tidur.

\section{The effect of Foot Massage on Sleep Quality of in ICU Rooms' Patients}

\begin{abstract}
Sleep disorders of critical patients in the Intensive Care Unit can result in impaired immune function, decrease respiratory muscle capacity, disruption of metabolic system, disruption of central nervous system regulation and psychological condition of patients impacting on long treatment period. Foot Massage is one of the complementary therapies that is considered safe and easy to administer and has the effect of improving circulation, removing the rest of the metabolism, increasing the range of motion of the joints, reducing the pain, relaxing muscles and providing comfort to the patient. The purpose of this study is to identify differences in the effect of sleep quality score on control and treatment groups. This quasi experimental study used a control group and a treatment group where each group performed a pretest and posttest assessment. The sample size was 24 patients. Sleep quality instrument used Richard Campbell Sleep Questionnaire (RCSQ). Data were analyzed by paired t test and unpaired $t$ test. The results showed that there was no significant difference in sleep quality score $(p=0,150)$, while in the treatment group, showed that there was a significant difference on sleep quality score $(\mathrm{p}=0,002)$. The difference of sleep quality score in control group and treatment group was significantly different $(p=0,026)$. Therefore, it can be concluded that sleep quality scores in the intervention group were higher than in the control group, thus foot massage is suggested to be used as evidence-based in hospitals as one of the complementary therapies that can be used as self-care interventions to help overcome patients with critical sleep disorder.
\end{abstract}

Keywords: Foot massage, ICU, sleep disorder. 


\section{Pendahuluan}

Pasien yang dirawat di ruang Intensive Care Unit (ICU), merupakan pasien-pasien yang mengalami gangguan fungsi tubuh yang dapat mengancam kehidupannya, dengan kondisi tidak stabil, sangat rentan terhadap serangan ataupun stresor, dan juga berbagai macam masalah karena biasanya pasien mengalami gangguan lebih dari satu sistem di tubuhnya serta kondisi pasien sendiri yang sulit untuk diprediksi (Alspach, 2006). Pasien dengan kondisi tersebut disebut juga dengan pasien kritis.

Ruang perawatan intensif merupakan bagian dari rumah sakit, dengan staf khusus dan peralatan khusus, ditujukan untuk observasi dan terapi pasien penyakit kritis yang dapat mengancam jiwa apabila tidak mendapatkan intervensi medis. Pasien kritis biasanya mengalami gangguan pada multi sistem yang melibatkan gangguan pada organ pernapasan, kardiovaskuler dan neurologi (Robertson \& Al-Haddads, 2013). Berdasarkan definisi tersebut maka pasien yang dirawat diruang intensif adalah pasien - pasien dengan kondisi kritis, penyakit yang kompleks dan rentan terhadap berbagai stressor.

Pasien yang dirawat di ruang ICU mengalami perubahan pada tidurnya dimana pasien yang mengalami sakit kritis mengalami jam tidur singkat sehingga membuat pasien mengalami kesulitan pencapaian REM dan tidur yang dalam, mengakibatkan pasien mudah terbangun (Weinhouse \& Schwab, 2006). Pada pasien yang mengalami perawatan di ruang ICU banyak pasien yang memiliki pengalaman gangguan tidur, penyebabnya diantaranya akibat kebisingan, intervensi yang diberikan serta pengobatan (Elliott, McKinley, Cistulli \& Fien, 2013).

Pasiensakitkritismenunjukkan fragmentasi tidur dimana efek yang ditimbulkan akan memengaruhi fungsi kekebalan tubuh, sistem metabolisme, regulasi sistem saraf pusat, dan kondisi psikologis. Sehingga tidur penting untuk proses pemulihan homeostasis integral (Weinhouse \& Schwab, 2006).

Masalah gangguan tidur pada pasien kritis dapat menyebabkan konsekuensi serius. Konsekuensi dari kualitas tidur yang buruk diantaranya meningkatkan gangguan pada kardiovaskular yaitu penyakit jantung koroner dan stroke, pada pernafasan dapat mengakibatkan hiperkapnia hingga hipoventilasi, gangguan metabolik yang terjadi terhadap toleransi glukosa, pelepasan insulin, sekresi hormon pertumbuhan dan kortisol, pengaturan nafsu makan oleh leptin dan gerlin, dan mempengaruhi kualitas tidur. Pengaruh yang terjadi pada sistem imun dapat meningkatkan resiko infeksi karena perubahan pada fungsi sel limfosit, sel polinuklear sel-sel pembunuh alami, dan inflamasi sitokonin (seperti IL-1, IL-6 dan TNF) hal ini dapat menyebabkan dampak kerusakan organ dan peningkatan mordibitas (Romero-Bermejo, 2014).

Tidur merupakan salah satu kebutuhan dasar manusia dimana kepentingannya sama dengan kebutuhan dasar lainnya. Tidur yang berkualitas baik dapat meningkatkan kesejahteraan psikologis dan sangat penting untuk penyembuhan dan kelangsungan hidup pasien dengan penyakit kritis (Richard, Crow, Codhill, \& Turnock, 2007; Kozier, Erb, Berman, \& Snyder, 2010).

Menurut National Hearth, Lung and Blood Institute (2011), tidur memberikan istirahat yang dibutuhkan oleh jantung dan sistem vaskuler. Selama tidur non-REM, detak jantung dan tekanan darah semakin lambat begitu juga ketika masuk kedalam kondisi tidur lebih dalam.

Kualitas tidur tidak selalu berhubungan dengan kuantitas tidur dimana kualitas tidur dikaitkan dengan sesuatu yang dirasakan secara subjektif yaitu kemudahan pasien untuk tidur, kemampuan memelihara tidur, total waktu tidur, bangun tidur diawal. Selain itu, beberapa hal yang dilaporkan terkait dengan kualitas tidur diantaranya perasaan gelisah di malam hari, perasaan cemas dan tegang, membutuhkan ketenangan saat mencoba untuk tidur. Kualitas tidur yang baik berhubungan dengan berbagai hasil positif seperti kesehatan yang lebih baik, kurang kantuk di siang hari, kesejahteraan yang lebih besar dan fungsi psikologis yang lebih baik. Kualitas tidur yang buruk salah satunya menggambarkan gejala insomnia kronis (Harvey, Stinson, Whitaker, Moskovitz \& Virk, 2008).

Seseorang yang mengalami kurang tidur memiliki banyak konsekuensi neurobiologis. 
Nurlaily Afianti : Pengaruh Foot Message terhadap Kualitas Tidur Pasien

Jika dalam satu malam seseorang melewati hari tanpa tidur maka terjadi penurunan kemampuan otak, perubahan perilaku yang paling terlihat adalah meningkatnya kecenderungan untuk jatuh tertidur, bahkan ketika orang tersebut berjuang untuk tetap terjaga. Sebaliknya, jika pada malam berikutnya kekurangan tidur dimodifikasi dan mengembalikan waktu tidur seperti biasanya maka yang terjadi memicu pemanjangan tidur malam hari, peningkatan tidur gelombang lambat, dan peningkatan tidur REM (Drouot \& Quentin, 2015).

Gangguan tidur di ICU disebabkan oleh banyak faktor, diantaranya lingkungan, kebisingan, pencahayaan, kegiatan perawat, penyakit yang diderita, tindakan keperawatan, terapi obat, dan ventilasi mekanik (Weinhouse \& Schwab, 2006; Talwar, Liman, Greenberg, Feinsilver, \& Vijayan, 2008).

Untuk mendapatkan kualitas tidur yang memadai, pasien bisa mendapatkan pengobatan baik farmakologi maupun non farmakologi. Penggunaan obat-obatan pada pasien di ICU diketahui memiliki dampak yang dapat mengganggu pada tidur dan pola sirkadian, dimana ketika malam hari mengalami penurunan kualitas tidur. Beberapa hal yang mengakibatkan gangguan tidur pada pasien di ICU diantaranya lingkungan, obatobatan, penggunaan ventilator, penyakit yang diderita oleh pasien (Hardin, 2009). Pada pasien kritis yang menjalani perawatan di ruang ICU dan mengalami gangguan tidur, umumnya digunakan sedasi untuk meminimalkan kegelisahan dan nyeri yang dapat mengganggu kebutuhan tidur pasien tersebut.

Penanganan gangguan tidur pada pasien kritis dengan farmakoterapi menurut Asnis, Thomas, dan Henderson (2016) dan Food and Drug Administration (FDA) sejak tahun 2005 menyetujui penggunaan semua hipnotik tanpa membatasi durasinya, diantaranya adalah benzodiazepin, nonbenzodiazepine, ramelteon, sinequan dosis rendah, dan suvorexant. Pada umumnya yang digunakan di ICU adalah golongan benzodiazepin, diantaranya lorazepam, midazolam, dan diazepam (Oldham \& Pisani, 2015).

Terapi lain yang digunakan adalah terapi komplementer, yang merupakan terapi tambahan umtuk membantu terapi konvensional yang direkomendasikan oleh penyelenggara kesehatan, seperti akupunktur, teknik pijatan pada tubuh, mind body techniques, pijat, dan metode lain yang dapat membantu meringankan gejala dan meningkatkan fisik serta mental. Selain itu, pijatan kaki selama 10 menit dapat memberikan efek yang baik pada tubuh (Deng \& Cassileth, 2005; Potter \& Perry, 2011).

Penanganan gangguan tidur pasien di ICU dapat diatasi dengan mengatur sistem pencahayaan, dengan tingkat pencahayaan lingkungan yang tepat dalam membantu pasien menimbulkan perasaan tenang dan nyaman (Engwall, Fridh, Johansson, Bergbom \& Lindhal, 2015). Cara lain yang digunakan untuk meningkatkan kualitas tidur dapat dilakukan dengan cara memodifikasi lingkungan yaitu menurunkan suara percakapan staf, menurunkan pencahayaan, mengatur kegiatan rutin perawatan dimalam hari (Hardin, 2009).

Massage therapy (MT) adalah suatu teknik yang dapat meningkatkan pergerakan beberapa struktur dari kedua otot dan jaringan subkutan, dengan menerapkan kekuatan mekanik ke jaringan. Pergerakan ini dapat meningkatkan aliran getah bening dan aliran balik vena, mengurangi pembengkakan dan memobilisasi serat otot, tendon dengan kulit. Dengan demikian, massage therapy dapat digunakan untuk meningkatkan relaksasi otot untuk mengurangi rasa sakit, stres, dan kecemasan yang membantu pasien meningkatkan kualitas tidur dan kecepatan pemulihan. Selain itu, massage therapy dapat meningkatkan pergerakan pasien dan pemulihan setelah operasi, yang memungkinkan pasien untuk melakukan aktivitas sehari-hari (Anderson \& Cutshall, 2007). Massage tidak hanya mengurangi emosi, gugup, tapi juga mempertahankan keseimbangan yang baik dari saraf vagus dan simpatik. Hal ini baik untuk mencegah stres dengan mengurangi kecemasan (Zhou, Zhang, \& Li, 2013)

Dari beberapa penelitian menggambarkan bahwa foot massage adalah salah satu metode yang paling umum dari terapi komplementer. Terapi pijat dan refleksi merupakan pendekatan terapi manual yang digunakan untuk memfasilitasi penyembuhan, 
Nurlaily Afianti : Pengaruh Foot Message terhadap Kualitas Tidur Pasien

kesehatan, dan dapat digunakan oleh perawat di hampir setiap pelayan perawatan (Kaur, Kaur, \& Bhardwaj, 2012).

Mekanisme foot massage yang dilakukan pada kaki bagian bawah selama 10 menit dimulai dari pemijatan pada kaki yang diakhiri pada telapak kaki diawali dengan memberikan gosokan pada permukaan punggungkaki, dimanagosokanyangberulang menimbulkan peningkatan suhu diarea gosokan yang mengaktifkan sensor syaraf kaki sehingga terjadi vasodilatasi pembuluh darah dan getah bening yang mempengaruhi aliran darah meningkat, sirkulasi darah menjadi lancar (Aditya, Sukarendra \& Putu, 2013). Foot massage mengaktifkan aktifitas parasimpatik kemudian memberikan sinyal neurotransmiter ke otak, organ dalam tubuh, dan bioelektrik ke seluruh tubuh. Sinyal yang di kirim ke otak akan mengalirkan gelombang alfa yang ada di dalam otak (Guyton, 2014). Impuls saraf yang dihasilkan saat melakukan foot massage diteruskan menuju hipotalamus untuk menghasilkan Corticotropin Releasing Factor (CRF). CRF merangsang kelenjar pituitary untuk meningkatkan produksi Proopioidmelanocortin (POMC) sehingga medulla adrenal memproduksi endorfin. Endorfin yang disekresikan ke dalam peredaran darah dapat mempengaruhi suasana hati menjadi rileks (Ganong, 2008).

Menurut Aziz (2014) Gelombang alfa akan membantu stres seseorang, sehingga stress akan hilang dan menjadikan orang tersebut merasa rileks dan membantu kontraksi otot untuk mengeluarkan zat kimia otak (neurotransmitter) menstimulasi RAS (Reticular Activating System) untuk melepaskan seperti hormone serotin, asetilkolin dan endorphine yang dapat memberikan rasa nyaman dan merelaksasi. Kemudian rasa rileks dan perasaan nyaman yang dirasakan dapat menurunkan produksi kortisol dalam darah sehingga memberikan keseimbangan emosi, ketegangan pikiran serta meningkatkan kualitas tidur (Azis, 2014).

Kaur, Kaur, dan Bhardwaj (2012) menyatakan bahwa foot massage yang dilakukan selama 5 menit pada pasien sakit kritis dapat memberikan efek meningkatkan relaksasi karena adanya perubahan pada tekanan darah sistolik, tekanan darah diastolik, denyut nadi, kelelahan, dan suasana hati setelah intervensi tersebut dilakukan. Pada tindakan foot massage berarti sentuhannya dapat merangsang oksitosin yang merupakan neurotransmiter di otak yang berhubungan dengan perilaku seseorang, dengan kata lain sentuhan merangsang produksi hormon yang menyebabkan perasaan aman dan menurunkan stres serta kecemasan (Mac Donald, 2010 \& Zak, 2012).

Foot Massage adalah manipulasi jaringan ikat melalui pukulan, gosokan atau meremas untuk memberikan dampak pada peningkatan sirkulasi, memperbaiki sifat otot dan memberikan efek relaksasi (Potter \& Perry, 2011).

Menurut Puthusseril (2006), foot massage mampu memberikan efek relaksasi yang mendalam, mengurangi kecemasan, mengurangi rasa sakit, ketidaknyamanan secara fisik, dan meningkatkan tidur pada seseseorang. Foot massage dapat memberikan efek untuk mengurangi rasa nyeri karena pijatan yang diberikan menghasilkan stimulus yang lebih cepat sampai ke otak dibandingkan dengan rasa sakit yang dirasakan, sehingga meningkatan sekresi serotonin dan dopamin. Sedangkan efek pijatan merangsang pengeluaran endorfin, sehingga membuat tubuh terasa rileks karena aktifitas saraf simpatis menurun (Field, Hernandez-Reif, Diego, \& Fraser, 2007; Gunnarsdottir \& Jonsdottir, 2007).

Morton dan Fonatin (2009) menunjukkan bahwa penanganan gangguan tidur saat ini bisa menggunakan terapi nonfarmakologi. Perawat dituntut agar dapat memberikan perawatan nonfarmakologi yang tidak memiliki pengaruh negatif dan dapat melengkapi terapi farmakologi yang selama ini sudah diberikan dalam perawatan pasien.

Untuk kondisi pasien di ruang ICU intervensi foot massage menjadi pilihan karena kaki mudah diakses tanpa memerlukan reposisi dari pasien dan juga massage pada kaki, selain merangsang sirkulasi dapat menurunkan edema dan latihan pasif untuk sendinya, serta melalui intervensi ini perawat dapat memberikan rasa nyaman dan kesejahteraan bagi pasien (Puthuseril, 2006; Prapti, Petpichetchian \& Chongcharoen, 2012). Tindakan foot massage memiliki pertimbangan biaya rendah, kemungkinan 
Nurlaily Afianti : Pengaruh Foot Message terhadap Kualitas Tidur Pasien

komplikasi yang sedikit dan prosedur yang mudah sehingga foot massage dianjurkan untuk perbaikan kualitas tidur (Oshvandi, Abdi1, Karampourian, Moghimbaghi \& Homayonfar, 2014).

Upaya memperbaiki kualitas tidur dengan menggunakan Foot Massage di ruang ICU dimana secara kultur budaya massage dapat diterima, dan foot massage aman diberikan pada pasien di ruang ICU, selain tidak perlu merubah posisi pasien, massage ini dapat memberikan rasa aman karena kehadiran perawat yang kontak langsung skin to skin terhadap pasien, sehingga hal tersebut melandasi penulis untuk melakukan penelitian tentang pengaruh foot massage terhadap kualitas tidur pada pasien di ruang ICU RSUP Dr. Hasan Sadikin Bandung. Tujuan penelitian ini adalah untuk mengetahui pengaruh foot massage terhadap kualitas tidur pasien di ruang ICU RSUP Dr. Hasan Sadikin Bandung.

\section{Metode Penelitian}

Rancangan penelitian yang digunakan dalam penelitian ini adalah Quasi Experiment dengan pendekatan Pretest and Posttest Control Group Design. Metode quasi experiment merupakan metode penelitian eksperimen dengan menggunakan kelompok kontrol. Pada rancangan ini responden penelitian dibagi secara acak menjadi dua kelompok. Satu kelompok adalah kelompok perlakuan, sedangkan kelompok lain adalah kelompok kontrol sebagai penguat (Dharma, 2011).

Pada rancangan ini sebelum peneliti melakukan intervensi pada semua kelompok dilakukan pengukuran awal (pretest) untuk mengetahui kualitas tidur awal responden sebelum diberikan intervensi. Selanjutnya pada kelompok intervensi dilakukan foot massage sesuai dengan langkah-langkah yang telah direncanakan, sedangkan pada kelompok kontrol tidak dilakukan foot massage. Setelah intervensi diberikan dilakukan pengukuran akhir (posttest) pada semua kelompok untuk menentukan efek foot massage terhadap kualitas tidur pada responden (Dharma, 2011).

Populasi dalam penelitian ini adalah pasien yang dirawat diruang ICU RSUP. Dr. Hasan Sadikin Bandung. Sedangkan sampel penelitian ini adalah yang memenuhi kriteria penelitian, kriteria inklusi: a). Kesadaran kompos mentis, b). Kooperatif, komunikatif dan ada kontak mata, c). Hemodinamik stabil sistolik 100-130 $\mathrm{mmHg}$, diastolik 60-100 $\mathrm{mmHg}$ dan MAP >65 mmHg tanpa menggunakan golongan inotropik dan support seperti: dobutamin, dopamin, epineprin dan norepineprin, d). Skala nyeri ringan dan sedang (skala 1-10), e). Responden yang menggunakan ventilator mode spontan ataupun yang tidak menggunakan ventilator dan kriteria Ekslusi: a). Responden tidak menggunakan analgetik narkotik dan sedatif, b). Responden yang mengalami fraktur, trauma, atau luka pada kaki, c). Responden dalam kondisi gelisah, d). Responden yang mempunyai manifestasi gejala trombosis vena dalam.

Besar Sampel pada penelitian ini Mengacu pada penelitian yang dilakukan oleh Oshvandi, Abdi, Karampurian, Homayonfar (2014), maka besar sampel untuk tiap kelompok adalah 11,5 dibulatkan menjadi 12 responden sedikitnya jumlah sampel untuk setiap kelompok. Dengan demikian maka besar sampel yang dipakai dalam penelitian ini adalah 24 responden, dengan uraian 12 responden untuk kelompok intervensi dan 12 responden untuk kelompok kontrol.

Penelitian ini dilaksanakan di ruang Intensive Care Unit (ICU) RSUP Dr. Hasan Sadikin Bandung. Peneliti memilih rumah sakit ini sebagai tempat penelitian dikarenakan Rumah Sakit Umum Pusat Jawa Barat merupakan rumah sakit rujukan tipe A terbesar di Jawa Barat dan memiliki fasilitas atau ruang perawatan intensif dewasa tersendiri. Ruang perawatan yang dipakai penelitian adalah ruang perawatan General Intensive Care Unit (GICU) lantai 2.

Pengukuran pretest dilakukan pada pagi hari jam $07.00 \mathrm{WIB}$, selanjutnya foot massage dilakukan pada malam hari menjelang pasien tidur jam 19.00-21.00 WIB selama dua hari berturut-turut. Foot massage diberikan selama 10 menit pada masing-masing bagian kaki sehingga total lama perlakuan 20 menit. Analisis uji homogenitas pada penelitian ini berdasarkan usia, jenis kelamin, lama hari rawat, riwayat gangguan tidur, nyeri, tingkat 
Nurlaily Afianti : Pengaruh Foot Message terhadap Kualitas Tidur Pasien

kecemasan, dan kebutuhan oksigen saat dilakukan penelitian. Diketahui data sebagian besar usia responden penelitian pada dua kelompok kontrol dan intervensi sebesar $45,83 \%$ berada dalam rentang usia dewasa awal 18-40 tahun, dimana jumlah responden laki-laki lebih banyak dari perempuan yaitu $54,16 \%$. Selama penelitian didapatkan data mayoritas pasien dirawat di ruang ICU dengan lama hari rawat pasien di ruang ICU $<7$ hari sebanyak 75\%. Berkaitan dengan riwayat gangguan tidur hampir sebagian besar pasien $(87,5 \%)$ mengalami gangguan tidur, hal ini ditunjang dengan tingkat nyeri yang dirasakan pasien $50 \%$ nyeri dengan intensitas nyeri sedang dan sebanyak $62,5 \%$ pasien ICU mengalami tingkat kecemasan sedang. Bantuan oksigenasi yang digunakan pasien di ICU bervariasi, selama penelitian terdapat sebanyak $37,49 \%$ pasien terpasang ventilator.
Uji homogenitas dilakukan dengan menggunakan uji tindependent (umur), uji Chi Squere (jenis kelamin, nyeri, oksigenasi, dan uji Fisher's exact (lama hari rawat, riwayat gangguan tidur, dan tingkat kecemasan) didapatkan bahwa seluruh karekteristik responden pada penelitian ini homogen atau tidak memiliki perbedaan dengan nilai signifikasi nilai $p>0,05$. Instrumen yang digunakan dalam penelitian ini adalah lembar isian yang berisi data sosial demografi, data klinis responden, protokol perlakuan foot massage, dan kuesioner penilain kualitas tidur menggunakan richard campbell sleep questionnaire (RSCQ).

Foot massage merupakan teknik dimana kedua kaki menerima beberapa teknik di berbagai posisi, dengan memijat lembut dan berirama untuk mendapatkan respon relaksasi (Puthusseril, 2006). Adapun langkah-langkah penatalaksanaan foot massage yang dilakukan

\begin{tabular}{ccl}
\hline No & Metode & \multicolumn{1}{c}{ Langkah-langkah Foot Massage } \\
\hline 1 & & $\begin{array}{l}\text { Dengan menggunakan bagian tumit telapak tangan peneliti, peneliti } \\
\text { menggosok dan memijat telapak kaki pasien secara perlahan dari arah } \\
\text { dalam ke arah sisi luar kaki pada bagian terluas kaki kanan selama } 15 \\
\text { detik. }\end{array}$
\end{tabular}

2

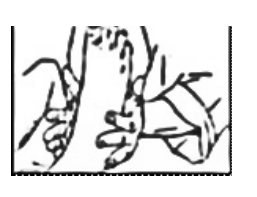

3

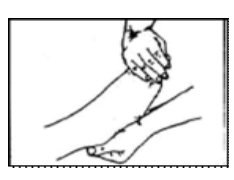

4

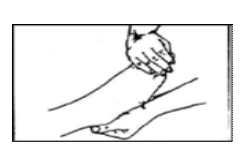

5
Dengan menggunakan tumit telapak tangan peneliti di bagian yang sempit dari kaki kanan, peneliti menggosok dan memijat secara perlahan bagian telapak kaki pasien dari arah dalam ke sisi luar kaki selama 15 detik.

Pegang semua jari-jari kaki oleh tangan kanan, dan tangan kiri menopang tumit pasien, kemudian peneliti memutar pergelangan kaki tiga kali searah jarum jam dan tiga kali ke arah berlawanan arah jarum jam selama 15 detik.

Tahan kaki di posisi yang menunjukkan ujung jari kaki mengarah keluar (menghadap peneliti), gerakan maju dan mundur tiga kali selama 15 detik. Untuk mengetahui fleksibilitas.
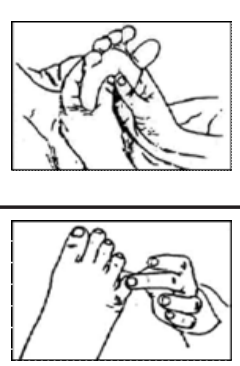

Tahan kaki di area yang lebih luas bagian atas dengan menggunakan seluruh jari (ibu jari di telapak kaki dan empat jari di punggung kaki) dari kedua belah bagian kemudian kaki digerakkan ke sisi depan dan ke belakang tiga kali selama 15 detik.

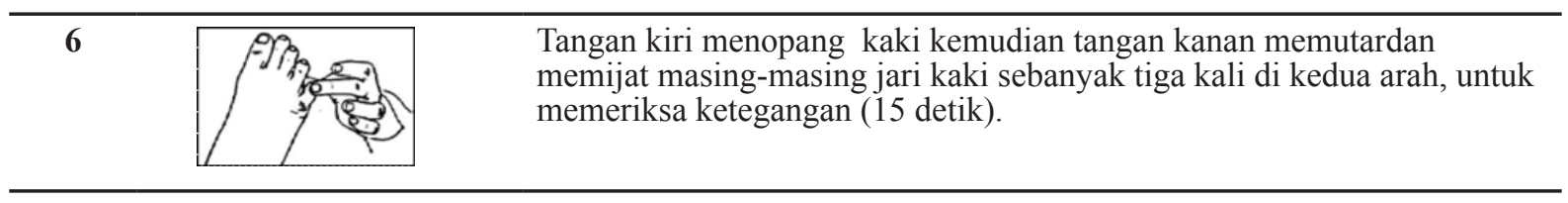




Pegang kaki kanan dengan kuat dengan menggunakan tangan kanan pada
bagian punggung kaki sampai ke bawah jari-jari kaki dan tangan kiri yang
menopang tumit. genggam bagian punggung kaki berikan pijatan lembut
selama 15 detik.

pada pasien adalah sebagai berikut:

\section{Hasil Penelitian}

Berdasarkan uji homogenitas dengan menggunakan uji $t$ independent (umur), Uji Chi Squere (jenis kelamin, nyeri, oksigenasi) dan Uji Fisher's exact (lama hari rawat, riwayat gangguan tidur, tingkat kecemasan) didapatkan bahwa seluruh karakteristik responden pada penelitian ini homogen atau tidak memiliki perbedaan dengan nilai signifikasi $p$ value $>0,05$.

Skor yang didapatkan dari pengukuran sebagai indikator kualitas tidur saat pretest dan posttest. Peneliti menggunakan uji t berpasangan ( $t$ dependent) untuk melihat perbedaan rerata skor kualitas tidur pada kelompok kontrol.
Berdasarkan tabel 2 diketahui bahwa nilai $p=0,150$ ( $p$ value $>0,05)$. Nilai ini menunjukkan tidak terdapat perbedaan yang bermakna rerata skor kualitas tidur pada kelompok kontrol.

Berikut ini adalah perbedaan rerata skor kualitas tidur pada kelompok intervensi (foot massage menjelang tidur) pada pengukuran saat pretest dan posttest. Analisis yang digunakan adalah uji $t$-dependent.

Berdasarkan tabel 3 diketahui bahwa nilai significancy $0,002(p<0,05)$ hal tersebut menunjukkan bahwa terdapat perbedaan skor kualitas tidur yang bermakna pada kelompok intervensi sebelum dan sesudah diberikan intervensi foot massage menjelang tidur selama 2 hari berturut-turut dengan lama pemijatan masing-masing kaki 10 menit. Hasil tersebut menunjukkan skor kualitas tidur lebih tinggi setelah diberikan perlakuan 
Nurlaily Afianti : Pengaruh Foot Message terhadap Kualitas Tidur Pasien

Tabel 1 Distribusi Frekuensi, Persentase, dan Uji Homogenitas Karekteristik Responden Kelompok Kontrol dan Intervensi $(\mathbf{N}=\mathbf{2 4})$ di Ruang ICU RSUP Dr. Hasan Sadikin Bandung Tahun 2016

\begin{tabular}{|c|c|c|c|c|}
\hline Karekteristik & Frekuensi (N) & & Persentase & p value \\
\hline & Kontrol & Intervensi & $(\%)$ & \\
\hline \multicolumn{5}{|l|}{ Usia } \\
\hline $\begin{array}{l}\text { Dewasa awal (18-40 } \\
\text { Tahun) }\end{array}$ & 6 & 5 & 45,83 & \\
\hline $\begin{array}{l}\text { Dewasa Menengah } \\
\text { (41-65 Tahun) }\end{array}$ & 5 & 4 & 37,5 & $0,376^{\mathrm{a}}$ \\
\hline $\begin{array}{l}\text { Dewasa Akhir }>65 \\
\text { Tahun }\end{array}$ & 1 & 3 & 16,67 & \\
\hline \multicolumn{5}{|l|}{ JenisKelamin } \\
\hline Laki-laki & 6 & 7 & 54,16 & $1,000^{\mathrm{b}}$ \\
\hline Perempuan & 6 & 5 & 45,83 & \\
\hline \multicolumn{5}{|l|}{ Lama Hari Rawat } \\
\hline$<7$ hari & 8 & 10 & 75 & $1,000^{\circ}$ \\
\hline$>7$ hari & 4 & 2 & 25 & \\
\hline \multicolumn{5}{|l|}{$\begin{array}{l}\text { Riwayat } \\
\text { GangguanTidur }\end{array}$} \\
\hline Ya & 10 & 11 & 87,5 & $1,000^{\circ}$ \\
\hline Tidak & 2 & 1 & 12,5 & \\
\hline \multicolumn{5}{|l|}{ Nyeri } \\
\hline Ringan & 7 & 5 & 50 & $0,683^{\mathrm{b}}$ \\
\hline Sedang & 5 & 7 & 50 & \\
\hline \multicolumn{5}{|l|}{$\begin{array}{l}\text { Tingkat } \\
\text { Kecemasan }\end{array}$} \\
\hline Ringan & 5 & 3 & 33,3 & \\
\hline Sedang & 7 & 8 & 62,5 & $0,667^{\mathrm{c}}$ \\
\hline Tinggi & - & 1 & 4,16 & \\
\hline \multicolumn{5}{|l|}{ Oksigenasi } \\
\hline Binasal & 4 & 4 & 33,3 & \\
\hline Simple Mask & 2 & 4 & 25 & \\
\hline T-Piece & 1 & - & 4,16 & $0,679^{\mathrm{b}}$ \\
\hline CPAP & 2 & 2 & 16,66 & \\
\hline $\mathrm{CPAP}+\mathrm{PS}$ & 3 & 2 & 20,83 & \\
\hline
\end{tabular}

foot massage.

Berikut ini merupakan distribusi perbedaan rerata skor kualitas tidur pada kelompok kontrol dan kelompok perlakuan. Sebelumnya dilakukan uji homogenitas varians melalui uji Levene diketahui data homogen (sig 0,365) maka untuk mengetahui perbedaan kualitas tidur pada kelompok kontrol dan intervensi menggunakan uji $t$ independent dengan varians sama dengan hasil sebagai berikut;

Berdasarkan data dari tabel 4 terlihat bahwa terdapat perbedaan secara bermakna selisih rerata skor kualitas tidur pada kelompok kontrol dan kelompok intervensi. Analisis yang digunakan adalah uji t tidak berpasangan ( $t$ independent $)$ hasil uji ini memiliki nilai signifikan $0,026(p<0,05)$. 
Nurlaily Afianti : Pengaruh Foot Message terhadap Kualitas Tidur Pasien

Tabel 2 Distribusi Rerata Skor Kualitas Tidur Kelompok Kontrol pada Pretest dan Posttest di Ruang ICU RSUP Dr. Hasan Sadikin Bandung

\begin{tabular}{cccccc}
\hline Kualitas Tidur & Mean & SD & SE & p value & N \\
\hline Pre & 49,76 & 10,281 & 2,968 & \multirow{2}{*}{0,150} & 12 \\
Post & 52,49 & 7,940 & 2,292 & & 12 \\
\hline
\end{tabular}

Tabel 3 Distribusi Rerata Skor Kualitas Tidur Responden Pretest dan Posttest pada Kelompok Intervensi Foot Massage di Ruang ICU RSUP Dr. Hasan Sadikin Bandung

\begin{tabular}{cccccc}
\hline Kualitas Tidur & Mean & SD & SE & p value & N \\
\hline Pre & 47,09 & 11,586 & 3,344 & 0,002 & 12 \\
Post & 60,69 & 8,861 & 2,558 & & 12 \\
\hline
\end{tabular}

Tabel 4 Analisis Perbedaan Rerata Skor Kualitas Tidur Pada Responden Kelompok Intervensi dan Kontrol Di Ruang ICU RSUP Dr. Hasan Sadikin Bandung

\begin{tabular}{cccccc}
\hline $\begin{array}{c}\text { Kualitas Tidur } \\
\text { Postest }\end{array}$ & Mean & SD & SE & p value & N \\
\hline Kontrol & 52,49 & 6,1305 & 1,7697 & 0,026 & 12 \\
Intervensi & 60,69 & 11,5323 & 3,3291 & & 12 \\
\hline
\end{tabular}

\section{Pembahasan}

Hasil penelitian kualitas tidur pada kelompok kontrol di tampilkan pada tabel 2, memiliki nilai skor awal kualitas tidur responden 49,76 dan skor kualitas tidur posttest 52,49. Pada kelompok tersebut skor kualitas tidur mengalami peningkatan sebesar 2,73 , setelah melalui uji t berpasangan $(t$ dependent) mendapatkan nilai $p=0,150$ ( $p$ value $>0,05$ ), hal ini menunjukan tidak terdapat perbedaan rerata skor kualitas tidur yang bermakna pada kelompok kontrol.

Tidak terdapatnya perbedaan yang bermakna pada kelompok kontrol mungkin saja dipengaruhi oleh sebagian besar responden kelompok kontrol mengalami tingkat kecemasan sedang dan adanya riwayat gangguan tidur selama perawatan di ruang ICU. Kemungkinan pula gangguan tidur disebabkan karena kecemasan. Kecemasan karena kondisi penyakit yang dialami, sebagian besar responden yang dirawat diruang ICU tidak hanya memiliki satu diagnosa tetapi memiliki 2 atau $>2$ diagnosa klinis, gangguan tidur pada kelompok kontrol kemungkinan pula disebabkan rasa terisolasi dari keluarga, kebisingan ruangan oleh suara alat-alat medis dan komunikasi antar tenaga kesehatan.

Hal ini ditunjang penjelasan Elliott, McKinley, Cistuli dan Fien (2013) bahwa pasien yang mengalami perawatan di ruang ICU mengalami gangguan tidur dimana mereka memiliki kualitas tidur yang kurang baik, penyebabnya bisa karena kebisingan, tingkat pencahayaan, tindakan pelayanan medis, pengobatan serta intervensi keperawatan. Menurut Gabor et al (2003) kegiatan perawatan bagi pasien meliputi, kunjungan perawatan, penilaian tandatanda vital dan pemberian obat-obatan yang diberikan saat jam tidur. Sekitar 20\% dari tindakan keperawatan mengakibatkan pasien terbangun. Selain itu juga tidak jarang pasien terganggu tidurnya akibat perawat yang memberikan tindakan keperawatan serta monitoring yang dilakukan setiap jamnya, walaupun peralatan ICU canggih, sehingga mengurangi manipulasi tangan terhadap pasien yang sedang tidur (Pulak \& Jensen, 2014).

Sejalan dengan hasil penelitian yang dilakukan oleh Oshvandi, Abdil, 
Nurlaily Afianti : Pengaruh Foot Message terhadap Kualitas Tidur Pasien

Karampourian, Monghimbaghi dan Homayonfar (2014) bahwa pada kualitas tidur kelompok kontrol tidak mengalami perbedaan yang bermakna $(p>0,05)$ pada pengukuran pretest dan posttest. Penelitian Kashani (2014) menunjukkan hasil penelitian tidak terdapat perbedaan yang signifikan antara nilai rata-rata dari kualitas tidur pretest dan posttest pada kelompok kontrol $(p>0,05)$.

Berdasarkan tabel 3, Adanya perbedaan pada kelompok intervensi sebelum dan sesudah intervensi, diketahui bahwa nilai significancy $0,002 \quad(p<0,05)$ hal tersebut menunjukkan bahwa terdapat perbedaan secara bermakna skor kualitas tidur pada kelompok intervensi sebelum dan sesudah diberikan intervensi foot massage. Adanya perbedaan ini dipengaruhi oleh pemberian foot massage.

Pemberian foot massage yang dimulai dari pemijatan kaki dan diakhiri dengan pemijatan telapak kaki merespon sensor syaraf kaki yang kemudian pijatan pada kaki ini meningkatkan neurotransmiter serotonin dan dopamin yang rangsangannya diteruskan ke hipotalamus dan menghasilkan Cortocotropin Releasing Factor (CRF) yang merangsang kelenjar pituary untuk meningkatkan produksi Proopioidmelanocortin (POMC) dan merangsang medula adrenal meningkatkan sekresi endorfin yang mengaktifkan parasimpatik sehingga terjadi vasodilatasi pada pembuluh serta memperlancar aliran darah sehingga membantu otot-otot yang tegang menjadi relaks sehingga RAS terstimulasi untuk melepaskan serotonin dan membantu munculnya rangsangan tidur serta meningkatkan kualitas tidur seseorang (Aditya, Sukarendra \& Putu, 2013; Guyton, 2014; Aziz, 2014; Pisani, Friese, Gehlbach, Schwab, Weiunhouse \& Jones, 2015).

Pemilihan foot massage sebagai intervensi yang digunakan pada pasien kritis dikarenakan kaki mudah diakses, pasien tidak perlu dilakukan reposisi sehingga tidak akan mempengaruhi peralatan yang digunakan oleh pasien, mampu merangsang sirkulasi peredaran darah yang dapat membuat suasana hati pasien menjadi nyaman, relaks, dan memiliki pengaruh yang positif sehingga akan mempengaruhi kualitas tidur pasien (Oshvandi, Abdil, Karampourian, Monghimbaghi, Homayonfar, 2014).
Berdasarkan tabel 4, Adanya perbedaan yang bermakna pada kelompok kontrol dan intervensi melalui uji $t$ independent mendapatkan hasil $p=0,026 \quad(p<0,05)$. Penelitian ini dianggap bermakna dengan menunjukkan bahwa terdapat pengaruh antara foot massage menjelang tidur terhadap peningkatan skor kualitas tidur pada kelompok intervensi di Ruang ICU RSUP Dr. Hasan Sadikin Bandung.

Penelitian ini sejalan dengan penelitian Kaur, Kaur, Bhardwaj (2012), intervensi foot massage berpengaruh terhadap penurunan denyut jantung ke arah normal dari responden yang diamatinya pada kelompok intervensi menunjukkan rata-rata denyut jantung dan respirasi menurun. Pada pasien yang mendapatkan intervensi massage ditemukan penurunan tekanan darah sistolik hasilnya berdampak pada pengaktifan sisitem saraf parasimpatis yang akan mengakibatkan penurunan respon fisiologis sehingga pasien merasa lebih santai (Cambon, Dexheimer, Coe, 2006 ; Kaye, Kaye, Swinford, Baluch, Bawcom, Lambert, 2008).

Rasa sakit yang dirasakan oleh pasien dapat dikurangi dengan menggunakan massage dimana rangsangan pijitan mampu mencapai otak lebih cepat dari rasa sakit itu sendiri dampaknya terjadi peningkatan serotonin, dopamin dan penurunan substansi P serta peningkatan produksi endorfin selama pemijatan yang menghasilkan efek relaksasi dan peningkatan tidur (Field, HernandezReif, Diego, Fraser, 2007).

Beberapa manfaat foot massage menunjukkan bahwa foot massage merupakan elemen yang mudah dan memiliki pengaruh besar. Menurut Trisnowiyanto (2012) dengan memberikan massage pada area kaki dapat memperlancar sistem peredaran darah, karena pijatan memberikan efek kenyamanan, sedatif dan mampu merangsang sistem syaraf dan meningkatkan aktifitas otot, sehingga pijatan pada kaki dapat mengendurkan otototot yang membuat pasien menjadi relaks.

Menurut Oshvandi, Abdi, Karampourian, Moghimbaghi, \& Homayonfar (2014) massage pada kaki memberi manfaat mengurangi kecemasan, stress dan nyeri yang dirasakan oleh pasien, sekalipun massage yang diberikan dalam waktu yang pendek dan hanya pada bagian kaki saja, dapat 
memberikan manfaat hati menjadi lebih tenang, stress berkurang dan peningkatan pada tidur.

Dengan demikian intervensi foot massage yang diberikan pada responden di ruang ICU meliputi gerakan sentuhan, pijatan serta mengurut kaki bagian bawah secara sistemik dan ritmik akan mengurangi ketegangan otot, menciptakan suasana relaks yang pada akhirnya dapat memperbaiki kualitas tidur pasien.

\section{Simpulan}

Simpulan dalam penelitian ini adalah tidak adanya perbedaan rerata skor kualitas tidur pada kelompok kontrol tetapi terdapat perbedaan secara bermakna pada kelompok perlakuan. Foot massage memiliki pengaruh positif terhadap kualitas tidur pasien di Ruang ICU, hal ini ditunjukkan dengan meningkatnya skor kualitas tidur pada kelompok intervensi setelah mendapatkan perlakuan foot massage secara signifikan dibandingkan dengan kelompok kontrol. Hal tersebut didukung oleh adanya perbedaan yang signifikan skor awal pretest antara kelompok kontrol dan kelompok intervensi dimana kelompok intervensi memiliki skor kualitas tidur lebih rendah dari skor kualitas tidur kelompok kontrol hal inilah yang menunjukkan bahwa foot massage memiliki pengaruh yang kuat dalam membatu memperbaiki kualitas tidur pasien di ruang ICU RSUP Dr. Hasan Sadikin Bandung.

\section{Daftar Pustaka}

Aditya, Sukarendra, \& Putu. (2013). Pengaruh pijat refleksi terhadap insomnia pada lansia di Desa Leyengan Kecamatan Ungaran Timur Kabupaten Semarang. Jurnal Keperawatan.

Alspach, J.G. (2006). Core curiculum for critical care nursing (6th Edition). Missouri Sounders Elsevier.

Anderson, P.G., \& Cutshall, A.M. (2007). Massage therapy - A comfort intervention for cardiac surgery patients. Clinical Nurse Specialist, 21, 161-5. doi:10.1097/01.
NUR.0000270014.97457.d5.

Asnis, G.M., Thomas, M., \& Henderson, M.A. (2016). Pharmacotherapy treatment options for insomnia: A primer for clinicians. International Journal of Molecular Sciences, 17(1), 50 .

Azis, M.T. (2014). Pengaruh terapi pijat (massage) terhadap tingkat insomnia pada lansia di Unit Rehabilitasi Sosial Pucang Gading Semarang. Jurnal keperawatan.

Badawi. (2009). Melawan dan Mencegah Diabetes : Panduan Hidup Sehat Tanpa Diabetes. Yogyakarta : Araska.

Deng, G., \& Cassileth, B.R.(2005). Integrative oncology: Complementary therapies for pain, anxiety and mood disturbance, CA career. Journal Clinic, 55, 10-16.

Dharma, K.K. (2011). Metodologi penelitian keperawatan. Jakarta: Trans Info Media.

Drouot, X., \& Quentin, S. (2015). Sleep neurobiology and critical care illness. Critical Care the Clinic, 31, 379-391.

Elliott, R.M., McKinley, S.M., \& Eagerm D. (2010). A pilot study of sound levels in an Australian Adult General Intensive Care Unit. Noise Health, 12(46), 26-36.

Engwalla, M., Fridha, I., Johansson, L., Bergbom, I., \& Lindahl, B. (2015). Lighting, sleep and circadian rhythm: An intervention study in the intensive care unit. Intensive and Critical Care Nursing, 31, 325-335.

Field, T., Hernandez-Reif, M., Diego, M., \& Fraser, M. (2007). Lower back pain and sleep disturbance are reduced following massage therapy. Journal Bodywork \& Movement Therapies, 11(2), 141-5.

Ganong, W. F. (2008). Buku ajar fisiologi kedokteran (Edisi 22). Jakarta: EGC.

Gunnarsdottir, T.J., \& Jonsdottir, H. (2007). Does the experimental design capture the effects of complementary therapy? A study using reflexology for patients undergoing coronary artery bypass graft surgery. Journal 
Nurlaily Afianti : Pengaruh Foot Message terhadap Kualitas Tidur Pasien

clinic Nursing, 16(4), 777-85.

Guyton, A.C., \& Hall, J.E. (2014). Buku ajar fisiologi kedokteran (Edisi 12). Saunders, Elseveir.

Hardin, K.A. (2009). Sleep in the ICU: Potential mechanisms and clinical implications. Chest, 136(1), 284-94. http:// dx.doi.org/10.1378/ chest.08-1546.

Harvey, A.G., Stinson, K., Whitaker, K. L., Moskovitz, D., \& Virk, H. (2008). The subjective meaning of sleep quality: A comparison of individuals with and without insomnia. Sleep, 31(3), 383-393.

Kaur, J., Kaur, S., \& Bhardwaj, N. (2012). Effect of 'foot massage and reflexology' on physiological parameters of critically ill patients. Nursing and Midwifery Research Journal, 8(3).

Kozier, Erb, Berman, \& Snyder. (2010). Buku ajar fundamental keperawatan: Konsep, proses \& praktik (Volume 1, Edisi 7). Jakarta: EGC.

MacDonald, K. (2010) The peptide that binds: A systematic review of oxytocin and its prosocial effects in humans. Harvard Review of Psychiatry, 18, 1-21.

Morton, P.G., \& Fontaine, D.K. (2009). Critical care nursing: A holistic approach (9th Edition). Philadelphia: Lippincott Raven Publisher.

National Center for Complementary and Alternative Medicine. (2009). Meditation: An Introduction, U.S. Departement of Health and Human Services, D308.

National Hearth, Lung and Blood Institute. (2011).

Nursalam. (2013). Konsep Penerapan Metode Penelitian Ilmu Keperawatan. Jakarta: Salemba Medika.

Oldham, M., \& Pisani, M.A. (2015). Sedation in Critically Ill Patients. Critical Care The Clinic. Vol:31 563-587
Oshvandi, Kh., Abdi, S., Karampourian, A., Moghimbaghi, A., \& Homayonfar, Sh. (2014). The effect of foot massage on quality of sleep in ischemic heart disease patients hospitalized in CCU. Iran Journal Critical Care Nurse, 7(2), 66-73.

Potter \& Perry. (2011). Fundamental of nursing (Buku 1, Edisi 8). Jakarta: Salemba Medika.

Pulak, L.M., \& Jensen, L. (2014). Sleep in the Intensive Care Unit: A Review. Journal of Intensive Care Medicine.

Puthusseril, V. (2006). Special foot massage as a complementary therapy in palliative care. Indian Journal of Palliative Care, 12(2), 7176.

Richardson, A., Crow, W., Coghill, E., \& Turnock, C. (2007) . A comparison of sleep assessment tools by nurses and patients in critical care. Journal Clininical Nursing, 16, 1660-8.

Robertson, L.C., \& Al-Haddad, M. (2013). Recognizing the critically ill patient. Anaesthesia and intensive care medicine, 14(1).

Romero-Bermejo, F.J. (2014). Sleep quality in intensive care unit: Are we doing our best for our patients?. Indian Journal Critical Care Medicine, 18, 191-2.

Trisnowiyanto, B. (2012). Instrumen pemeriksaan fisioterapi \& penelitian kesehatan. Yogyakarta: Nuha Medika.

Weinhouse, G.L., \& Schwab, R.J. (2006) Sleep in the critically ill patient. SLEEP, 29(5), 707-716.

Zak, P. (2012) The moral molecule: The source of love and prosperity. New York, NY: Penguin Group.

Zhou, X., Zhang, S., \& Li, X. (2013). Application of relaxation training and its enlightenment for nursing. Chinese Journal of Nursing, 39, 129-130. 